\title{
HAK KHUSUS TENAGA KERJA WANITA DALAM MEMBERIKAN ASI EKSKLUSIF DI PROVINSI BALI ${ }^{1}$
}

\author{
Oleh: \\ Putu Angga Pratama Sukma²
}

\begin{abstract}
Article $28 H$ verse (2) of the Constitution c of Indonesia year 1945 (UUD 45) stated that everyone is entitled to get the easiness and special treatment to obtain the same opportunity and benefit to achieve the equality and justice. Special rights for female workers to treat the babies by way of providing Exclusive Breast Milk while working is protected and respected since Republic of Indonesia is a Nation based on the rule of Law and upholding the Human Rights. The regulation regarding the special rights for female workers in providing Exclusive Breast Milk in Province of Bali is still unavailable since it still has not carried out the assessment and alignment, even though the infant mortality rate in Province of Bali since January up to May 2015 was recorded at 187 babies aged between 0-12 months. Therefore the problem is formulated: How is the responsibility of Regional Government of Province of Bali regarding special rights for female workers in providing Exclusive Breast Milk? And how is the regulation in upholding special rights for female workers in providing Exclusive Breast Milk in Province of Bali? The type of research was using normative research method. With the type of approach was using The Statute Approach and Analytical and Conceptual Approach. The responsibility of regional government of Province of Bali as an authority and legitimate holder, is obliged to setup and carry out the policy both juridical and non-juridical in compliance with infant rights aged between 0-6 months and the rights for female workers in the protection of Exclusive Breast Milk in general implementation aligned with the assessment and alignment hierarchy of The Government Regulation Number 33 year 2012 concerning the Providing of Exclusive Breast Milk.
\end{abstract}

Keywords: Exclusive Breast Milk, Infant Rights, Special Rights for Female Workers, The Regional Government of Province of Bali.

\footnotetext{
Absrak

Pasal 28 H ayat (2) Undang Undang Dasar Negara Republik Indonesia Tahun 1945 (UUD 45) yang menyatakan setiap orang berhak mendapat kemudahan dan perlakuan khusus untuk memperoleh kesempatan dan manfaat yang sama guna mencapai persamaan dan keadilan. hak perlakuan khusus bagi tenaga kerja wanita untuk mensejahterakan bayi dengan cara memberikan ASI Eksklusif walaupun sedang bekerja yang dilindungi dan dihormati karena Negara Indonesia adalah Negara Hukum dan menjunjung tinggi HAM. Pengaturan mengenai hak khusus

Artikel ini merupakan penelitian/karya ilmiah mahasiswa pada Program Studi Magister (S2) Ilmu Hukum Program Pascasarjana Universitas Udayana dan mengucapkan terimakasih kepada Penyunting Ahli adalah Dr. Ida Bagus Surya Dharma Jaya, SH. M.H, dan Penyunting Teknis adalah I Nyoman Bagistra, S.H., M.H.

2 Penulis adalah mahasiswa magister ilmu hukum Universitas Udayana Denpasar, Bali. Alamat Jalan Palapa Raya no. 21, Sesetan, Denpasar, email: angga.sukma21@gmail.com
} 
tenaga kerja wanita dalam memberikan ASI Eklusif di Provinsi Bali masih kosong karena belum dilakukan pengkajian dan penyelarasan, padahal angka kematian bayi di Provinsi Bali dari bulan Januari-Mei 2015 tercatat 187 bayi berusia 0-12 bulan. Maka dari itu dirumuskan masalah: Bagaimana tanggung jawab Pemerintahan Daerah Provinsi Bali mengenai hak khusus bagi tenaga kerja wanita dalam memberikan ASI eksklusif? Dan Bagaimana pengaturan dalam menegakan hak khusus bagi tenaga kerja wanita dalam memberikan ASI eksklusif di Provinsi Bali?. Jenis penelitian ini menggunakan metode penelitian normative yang merupakan penelitian mengenai substansi hukum yang terdiri dari norma, kaidah, asas-asas hukum, doktrin dan peraturan perundang-undangan. Dengan jenis pendekatan menggunakan: The Statute Approach and Analitical and Conceptual Approach. Tanggung jawab pemerintahan daerah provinsi Bali sebagai pemegang otoritas dan legitimasi, diwajibkan untuk menyusun dan menjalankan kebijakan baik yuridis maupun nonyuridis dalam pemenuhan Hak anak yang berusia 0-6 bulan dan Hak tenaga kerja wanita dalam perlindungan ASI Ekslusif tersebut dalam penyelenggaraan umum dengan Asas Dekonsentrasi dan Asas Tugas Pembantuan melaksanakan kebijakan nasional dalam rangka program pemberian ASI Eksklusif selaras dengan pengkajian dan penyelarasan hierarki Peraturan Pemerintah Nomor 33 Tahun 2012 Tentang Pemberian Air Susu Ibu Eksklusif.

Kata Kunci: ASI Ekslusif, Hak Anak, Hak Khusus Tenaga Kerja Wanita, Pemerintahan Daerah Provinsi Bali.

\section{PENDAHULUAN}

\subsection{Latar Belakang}

Segala sesuatu harus dilakukan menurut hukum (everything must be done according to law). Pemikiran hak perlakuan khusus bagi tenaga kerja wanita dalam memberikan ASI (Air Susu Ibu) eksklusif di tempat kerja walaupun tidak eksplisit tetapi secara abstrak tercantum dalam Pasal $28 \mathrm{H}$ ayat (2) Undang Undang Dasar Negara Republik Indonesia Tahun 1945 (UUD 45) yang menyatakan "setiap orang berhak mendapat kemudahan dan perlakuan khusus untuk memperoleh kesempatan dan manfaat yang sama guna mencapai persamaan dan keadilan". Pasal ini mengandung makna bahwa seseorang wajib tunduk kepada seseorang dengan pertimbangan moral dan etika untuk memperoleh kesempatan dan manfaat yang sama guna mencapai persamaan dan keadilan.

Pengakuan hak perlakuan khusus sebagai bagian dari HAM sebagaimana diatur dalam Pasal 41 ayat (2) Undang Undang Nomor 39 Tahun 1999 Tentang Hak Asasi Manusia (UU HAM) yang menyatakan "setiap penyandang cacat, orang yang berusia lanjut, wanita hamil, dan anak-anak, berhak memperoleh kemudahan dan perlakuan khusus". Pengertian anak dalam hal ini terdapat dalam Pasal 1 angka 5 "anak adalah setiap manusia yang berusia di bawah 18 (delapan belas) tahun dan belum menikah, termasuk anak yang masih 
dalam kandungan apabila hal tersebut adalah demi kepentingannya". Dalam Pasal 1 angka 2 Peraturan Menteri Negara Pemberdayaan Perempuan dan Perlindungan Anak Republik Indonesia Nomor 11 Tahun 2011 Tentang Kebijakan Pengembangan Kabupaten/ Kota Layak Anak (PERMENPPPA KLA) "hak anak adalah bagian dari hak asasi manusia yang wajib dijamin, dilindungi, dan dipenuhi oleh orang tua, keluarga, masyarakat, pemerintah, dan negara".

Perusahaan kebanyakan mempekerjakan tenaga kerja perempuan dalam perusahaanya, karena pekerja perempuan dianggap lebih teliti dalam bekerja. $^{3}$ Dalam penjelasan umum Undang Undang nomor 13 Tahun 2003 Tentang Ketenagakerjaan (UU Ketenagakerjaan) pembangunan ketenagakerjaan harus diatur sedemikian rupa sehingga terpenuhi hak-hak dan perlindungan yang mendasar bagi tenaga kerja dan pekerja/buruh. Hal ini diperkuat dalam Pasal 4 huruf $d$ yaitu "pembangunan ketenagakerjaan bertujuan meningkatkan kesejahteraan tenaga kerja dan keluarganya". Secara eksplisit pasal ini memberikan kemudahan bagi tenaga kerja wanita untuk mensejahterakan bayi dengan cara memberikan ASI Eksklusif walaupun ibu sedang bekerja. Dimana

Diah Fitriani, 2015, Penjabaran Hak Tenaga Kerja Perempuan Atas Upah Dan Waktu Kerja Dalam Peraturan Perusahaan Dan Perjanjian Kerja, Jurnal Magister Hukum Udayana (Udayana Master Law Journal), vo. 4 , no. 2 , hlm. 374 . dalam hal ini Pasal 129 ayat(1) Undang Undang Nomor 36 Tahun 2009 Tentang Kesehatan (UU Kesehatan) "pemerintah bertanggung jawab menetapkan kebijakan dalam rangka menjamin hak bayi untuk mendapatkan air susu ibu secara eksklusif'. Dalam Peraturan Pemerintah Nomor 33 Tahun 2012 Tentang Pemberian Air Susu Ibu Eksklusif (PP ASI Eksklusif) Pasal 1 angka 2 "Air Susu Ibu Eksklusif yang selanjutnya disebut ASI Eksklusif adalah ASI yang diberikan kepada Bayi sejak dilahirkan selama 6 (enam) bulan, tanpa menambahkan dan/atau mengganti dengan makanan atau minuman lain".

Dalam penjelasan umum PP ASI Eksklusif upaya pembangunan kesehatan sebagai bagian dari pembangunan nasional agar dapat meningkatkan derajat kesehatan masyarakat yang setinggi-tingginya antara lain adalah penurunan angka kematian Bayi. Salah satu indikator keberhasilan pembangunan kesehatan antara lain adalah penurunan angka kematian Bayi. Pola pemberian makan terbaik untuk Bayi sejak lahir sampai anak berumur 2 (dua) tahun meliputi: (a)memberikanASIkepada Bayi segera dalam waktu 1 (satu) jam setelah lahir; (b) memberikan hanya ASI saja sejak lahir sampai umur 6 (enam) bulan. Memberikan ASI menurunkan risiko infeksi akut seperti diare, pnemonia, infeksi telinga, haemophilus influenza, meningitis dan infeksi saluran kemih. Memberikan ASI juga melindungi Bayi dari penyakit kronis masa depan 
seperti diabetes tipe 1, penurunan tekanan darah dan kolesterol serum total, serta kelebihan berat badan dan obesitas pada masa remaja dan dewasa.

Manfaat ekomomi pemberian ASI kepada bayi lebih murah ketimbang membeli susu formula dan tidak merusak lingkungan akibat pembuangan sampah bekas susu formula. Pengaturan mengenai hak khusus tenaga kerja wanita dalam memberikan ASI Eklusif di Provinsi Bali belum diatur dalam Peraturan Daerah, padahal angka kematian bayi di Provinsi Bali dari bulan JanuariMei 2015 tercatat 187 bayi berusia 0-12 bulan ${ }^{4}$, yang terindikasi rawan penyakit yang dapat menurunkan risiko infeksi akut seperti diare, pnemonia, infeksi telinga, haemophilus influenza, meningitis dan infeksi saluran kemih yang mengakibatkan bayi sakit dan menyebabkan kematian. Maka dari itu diperlukan upaya preventif seperti membuat peraturan daerah guna menurunkan angka kematian bayi di Provinsi Bali.

\subsection{Perumusan Masalah}

1. Bagaimanakah tanggung jawab Pemerintahan Daerah Provinsi Bali mengenai hak khusus bagi tenaga kerja wanita dalam memberikan ASI eksklusif?

2. Bagaimanakah seharunya pengatur-an hak khusus bagi

Tribun Bali, 27 Juni 2015, Angka Kematian Ibu dan Bayi di Bali Menurun di Tahun 2015, hlm.2. tenaga kerja wanita dalam memberikan ASI eksklusif dalam bentuk Peraturan Daerah di Provinsi Bali?

\subsection{Tujuan Penelitian}

Penelitian ini memiliki tujuan sebagai berikut:

1. Untuk mengetahui tanggung jawab Pemerintahan Daerah Provinsi Bali mengenai hak khusus bagi tenaga kerja wanita dalam memberikan ASI eksklusif.

2. Untuk prinsip pengaturan hak khusus bagi tenaga kerja wanita dalam memberikan ASI eksklusif di Provinsi Bali.

\section{METODE PENELITIAN}

Jenis penelitian ini menggunakan metode penelitian normatif. Penelitian normatif merupakan penelitian mengenai substansi hukum yang terdiri dari norma, kaidah, asas-asas hukum, doktrin dan peraturan perundangundangan. ${ }^{5}$ Pada penelitian jenis ini acapkali hukum dikonsepkan sebagai apa yang tertulis dalam peraturan perundang-undangan (law in books) atau hukum dikonsepkan suatu kaedah atau norma yang merupakan patokan berperilaku manusia yang dianggap pantas. ${ }^{6}$ Penelitian hukum ini tergolong penelitian hukum normatifdikarenakan

\footnotetext{
Mukti Fajar dan Yulianto Achmad, 2010, Dualisme Penelitian Hukum Normatif dan Empiris, PT Pustaka Pelajar, Yogyakarta, hlm. 28.

6 Amirudin dan Zainal Asikin, 2005, Pengantar Metode penelitian Hukum, PT Raja Grafindo Persada, Jakarta, hlm. 18.
} 
Pemerintah Derah Provinsi Bali belum membuat suatu peraturan mengenai ASI Eksklusif yang telah diamandatkan dalam Pasal 129 UU Kesehatan dan PP ASI Eksklusif.

Jenis pendekatan dalam penelitian ini menggunakan: 1) Pendekatan Perundang-undangan (The Statute Approach). Dalam hal ini peneliti melakukan analisis terhadap peraturan-peraturan yang terkait dengan kebijakan tentang pembangunan kesehatan dan pembangunan ketenaga-kerjaan; 2) Pendekatan Analisis Konsep Hukum (Analitical and Conceptual Approach). Dalam hal ini peneliti melakukan analisis terhadap konsepkonsep hukum yang berhubungan dengan pembangunan kesehatan dan pembangunan ketenagakerjaan yang menjadidasar adanya kebijakantentang ASI Eksklusif, serta pemenuhan hak asasi manusia terutama tenaga kerja wanita dan bayi yang berumur 0-6 bulan.

Sumber bahan hukum yang digunakan di dalam penelitian ini adalah bahan hukum primer, bahan hukum sekunder dan bahan huku tersier. Baha hukum primer seperti UUD'45, UU HAM, UU Kesehatan, PP ASI Eksklusif. Bahan hukum sekunder berupa buku hukum, jurnal hukum, media cetak dan media elektronik yang memberikan penjelasan mengenai ASI Eksklusif ini.

Teknik pengumpulan bahan hukum dilakukan dengan prosedur inventarisasi mempelajari dan mendalami bahan-bahan hukum primer, sekunder dan tersier yang berkaitan dengan penelitian ini. Bahan hukum yang diperoleh dikumpulkan dengan mempergunakan sistem kartu (card system). Kemudian dilakukan pencatatan mengenai hal-hal yang dianggap penting dan berguna bagi penelitian. Dan teknik analisis bahan hukum menggunakan teknik deskripsi dengan memaparkan terlebih dahulu kemudian dianalisa dan selanjutnya disimpulkan.

\section{HASIL DAN PEMBAHASAN \\ 3.1 Tanggung Jawab Pemerintahan Daerah Provinsi Bali Mengenai Hak Khusus Bagi Tenaga Kerja Wanita Dalam Memberikan ASI Eksklusif}

Negara Indoenesiaadalah Negara hukum demikian tercantum dalam Pasal 1 ayat (3) UUD '45 Menurut Friedrich J. Stahl, menyatakan bahwa mengenai negara hukum ditandai oleh empat unsur pokok yaitu: ${ }^{7}$

a. Adanya jaminan atas hak-hak asasi manusia;

b. Adanya pembagian kekuasaan;

c. Pemerintahan haruslah berdasarkan peraturan-peraturan hukum (wetmatig van bestuur); dan

d. Adanya peradilan administrasi negara (PTUN) yang bertugas menangani kasus perbuatan melanggar hukum oleh

Dasril Radjab, 2005, Hukum Tata Negara Indonesia, Rineka Cipta, Jakarta, hlm. 77. 
pemerintah (onrechtmatige overheidsdaad).

Dalam Pasal 1 angka 2 Undang Undang Nomor 23 Tahun 2014 Tentang Pemerintahan Daerah (UU Pemerintahan Daerah), Pemerintahan Daerah adalah penyelenggaraan urusan pemerintahan oleh pemerintah daerah dan dewan perwakilan rakyat daerah menurut asas otonomi dan tugas pembantuan dengan prinsip otonomi seluas-luasnya dalam sistem dan prinsip Negara Kesatuan Republik Indonesia sebagaimana dimaksud dalam Undang-Undang Dasar Negara RepublikIndonesia Tahun 1945. Dalam penyelenggaraan unsur pemerintahan di daerah, maka dilaksanakan melalui 3 (tiga) asas yaitu: 1) Asas Desentralisasi, 2) Asas Dekonsentrasi, dan 3) Asas Tugas Pembantuan. ${ }^{8}$ Terkait mengenai hak khusus bagi tenaga kerja wanita dalam memberikan ASI eksklusif yang sudah diatur dalam Pasal 129 ayat (1) UU Kesehatan yang dijabarkan ke dalam PP ASI Eksklusif yang mewajibkan dan memberikan tanggung jawab sebagai daerah otonom yaitu Pemerintahan Provisi Bali dalam membentuk perda tentang ASI Eksklusif, dengan acuan Pasal 236 ayat (3) huruf b UU Pemerintahan Daerah, Perda sebagaimana dimaksud pada ayat (1) memuat materi muatan: penjabaran lebih lanjut ketentuan peraturan perundang-undangan yang lebih tinggi. Dalam Pasal 7 ayat (1) Undang Undang Nomor 12

Siswanto Sunarno, 2006, Hukum Pemerintahan Daerah di Indonesia, Sinar Grafika, Jakarta, hlm. 7.
Tahun 2011 Tentang Pembentukan Peraturan Perundang Undangan (UU PP Perundang Undangan) jenis dan hierarki Peraturan Perundangundangan terdiri atas:

a. Undang-Undang Dasar Negara Republik Indonesia Tahun 1945;

b. Ketetapan Majelis Permusyawaratan Rakyat;

c. Undang-Undang/Peraturan Pemerintah Pengganti UndangUndang;

d. Peraturan Pemerintah;

e. Peraturan Presiden;

f. Peraturan Daerah Provinsi; dan

g. Peraturan Daerah Kabupaten/ Kota.

Dalam Pasal 7 ayat (2) Kekuatan hukum Peraturan Perundangundangan sesuai dengan hierarki sebagaimana dimaksud pada ayat (1). Dalam penjelasan umum Pasal 7 ayat (2) Dalam ketentuan ini yang dimaksud dengan "hierarki" adalah penjenjangan setiap jenis Peraturan Perundang-undangan yang didasarkan pada asas bahwa Peraturan Perundangundangan yang lebih rendah tidak boleh bertentangan dengan Peraturan Perundang-undangan yang lebih tinggi.

Tercantumnya di dalam Pasal 2 PP ASIEksklusifmengenai Pengaturan pemberian ASI Eksklusif bertujuan untuk: a. menjamin pemenuhan hak Bayi untuk mendapatkan ASI Eksklusif sejak dilahirkan sampai dengan berusia 6 (enam) bulan dengan memperhatikan pertumbuhan dan 
perkembangannya; b. memberikan perlindungan kepada ibu dalam memberikan ASI Eksklusif kepada bayinya; dan c. meningkatkan peran dan dukungan Keluarga, masyarakat, Pemerintah Daerah, dan Pemerintah terhadap pemberian ASI Eksklusif. Serta tanggung jawab pemerintahan daerah provinsi tersirat dalam Pasal 4 Tanggung jawab pemerintah daerah provinsi dalam program pemberian ASI Eksklusif meliputi: a. melaksanakan kebijakan nasional dalam rangka program pemberian ASI Eksklusif; b. melaksanakan advokasi dan sosialisasi program pemberian ASI Eksklusif dalam skala provinsi; c. memberikan pelatihan teknis konseling menyusui dalam skala provinsi; d. menyediakan tenaga konselor menyusui di Fasilitas Pelayanan Kesehatan dan tempat sarana umum lainnya dalam skala provinsi; e. membina, monitoring, mengevaluasi, dan mengawasi pelaksanaan dan pencapaian program pemberian ASI Eksklusif di Fasilitas Pelayanan Kesehatan, satuan pendidikan kesehatan, Tempat Kerja, tempat sarana umum, dan kegiatan di masyarakat dalam skala provinsi; f. menyelenggarakan, memanfaatkan, dan memantau penelitian dan pengembangan program pemberian ASI Eksklusif yang mendukung perumusan kebijakan provinsi; g. mengembangkan kerja sama dengan pihak lain sesuai dengan ketentuan peraturan perundang-undangan; dan h. menyediakan ketersediaan akses terhadap informasi dan edukasi atas penyelenggaraan pemberian

ASI Eksklusif dalam skala provinsi.

Terkait dengan prinsip tanggung jawab dalam hak asasi manusia terdapat 3 bentuk kewajiban yang harus dilakukan yaitu kewajiban untuk menghormati(an obligation torespect), kewajiban untuk melindungi (an obligation to protect) dan kewajiban untuk memenuhi (an obligation to fulfill). ${ }^{9}$ Dan pemerintah/ pemerintah daerah wajib dan bertanggung jawab menghormati, melindungi, menegakkan, dan memajukan hak asasi manusia yang diatur dalam dalam UU HAM.

Dikarenakan tidak adanya aturan tertulis atau kekosongan norma mengenai pengaturan ASI eksklusif di Pemerintahan Provinsi Bali yang merupakan Hak Anak dalam terpenuhinya kesehatan dasar serta Hak wanita dalam perlakuan khusus dalam tanggung jawabnya memberikan ASI kepada anaknya walaupun wanita tersebut sedang bekerja. Tanggung jawab pemerintahan daerah provinsi Bali dalam program pemberian ASI Eksklusif sebagai daerah otonom yang menganut asas Dekonsentrasi dan Tugas Pembantuan melaksanakan kebijakan nasional dalam rangka program pemberian ASI Eksklusif

Putu Eva Laheri, 2015, Tanggung Jawab
Negara Terhadap Kerugian Wisatawan
Berkaitan Dengan Pelanggaran Hak
Berwisata Sebagai Bagian Dari Hak Asasi
Manusia, lihat Christian Tomuschat, 2008,
Human Rights between Idealism and Realism,
Oxford University Press, Oxford, page. 43,
Jurnal Magister Hukum Udayana (Udayana
Master Law Journal), vol.4, no. 1, hlm. 127. 
dengan membentuk Peraturan Daerah dan Peraturan Kepala Daerah.

\subsection{Pengaturan Hak Khusus Bagi} Tenaga Kerja Wanita Dalam Memberikan ASI Eksklusif Di Masa Mendatang Di Provinsi Bali

Dalam UU PP Perundang Undangan mengenai pembentukan Peraturan Daerah harus disusun dalam perencanaan penyusunan yang dilakukan oleh Program Legislasi Daerah (Prolegda) Provinsi yang memuat judul Rancangan Peraturan Daerah Provinsi, materi yang diatur, dan keterkaitannya dengan Peraturan Perundang-undangan lainnya dengan konsepsi yang meliputi: a. latar belakang dan tujuan penyusunan; $b$. sasaran yang ingin diwujudkan; c. pokok pikiran, lingkup, atau objek yang akan diatur; dan d. jangkauan dan arah pengaturan; yang telah melalui pengkajian dan penyelarasan dituangkan dalam Naskah Akademik. Yang dimaksud dengan "pengkajian dan penyelarasan" adalah proses untuk mengetahui keterkaitan materi yang akan diatur dengan Peraturan Perundang-undangan lainnya yang vertikal atau horizontal sehingga dapat mencegah tumpang tindih pengaturan atau kewenangan. Kedudukan hukum peraturan daerah secara hierarki Peraturan Perundang-Undangan, pada Pasal 7, yang menempatkan peraturan daerah kedalam urutan keenam dengan peraturan pemerintah urutan keempat. Menurut Bagir Manan, agar pembentukan undang-undang menghasilkan suatu undang-undang yang tangguh dan berkualitas terdapat tiga landasan dalam menyusun undang-undang: 1) Landasan yuridis (juridische gelding); 2) Landasan sosiologis (sociologische gelding) dan; 3) Landasan filosofis ${ }^{10}$

\begin{tabular}{|l|l|}
\hline Landasan & \multicolumn{1}{c|}{ Penjelasan Mengenai ASI Eksklusif } \\
\hline 1. Pasal 18 ayat (6) UUD '45 "Pemerintahan daerah berhak menetapkan \\
peraturan daerah dan peraturanperaturan lain untuk melaksanakan otonomi \\
dan tugas pembantuan. Pemerintahan daerah berhak menetapkan peraturan \\
daerah dan peraturanperaturan lain untuk melaksanakan otonomi dan tugas \\
pembantuan."
\end{tabular}

Yuliandri, 2013, Asas-Asas Pembentukan Peraturan Perundang-Undangan Yang Baik: Gagasan Pembentukan Undang-Undang Berkelanjutan, dikutip dari Bagir Manan, Dasar-Dasar Konstitusional Peraturan Perundang Undangan Nasional, Cetakan ke IV, PT Raja Grafindo Persada, Jakarta, hlm. 29. 


\begin{tabular}{|l|l|}
\hline 1. & $\begin{array}{l}\text { Demi mengamanatkan Pancasila terutama sila ke dua "Kemanusian Yang } \\
\text { Adil dan Beradab" }\end{array}$ \\
2. & Penjelasan Umum PP ASI Eksklusif: \\
Pembangunan kesehatan sebagai bagian dari pembangunan nasional \\
diarahkan pada peningkatan kualitas sumber daya manusia dan dilaksanakan \\
guna tercapainya kesadaran, kemauan dan kemampuan untuk hidup sehat \\
bagi setiap penduduk agar dapat meningkatkan derajat kesehatan masyarakat \\
yang setinggi-tingginya. Salah satu indikator keberhasilan pembangunan \\
kesehatan antara lain adalah penurunan angka kematian Bayi. Pola pemberian \\
makan terbaik untuk Bayi sejak lahir sampai anak berumur 2 (dua) tahun \\
meliputi: (a) memberikan ASI kepada Bayi segera dalam waktu 1 (satu) \\
jam setelah lahir; (b) memberikan hanya ASI saja sejak lahir sampai umur \\
6 (enam) bulan. Hampir semua ibu dapat dengan sukses menyusui diukur \\
dari permulaan pemberian ASI dalam jam pertama kehidupan Bayi. Menyusui \\
menurunkan risiko infeksi akut seperti diare, pnemonia, infeksi telinga, \\
haemophilus influenza, meningitis dan infeksi saluran kemih. Menyusui juga \\
melindungi Bayi dari penyakit kronis masa depan seperti diabetes tipe 1. \\
Menyusui selama masa Bayi berhubungan dengan penurunan tekanan darah \\
dan kolesterol serum total, berhubungan dengan prevalensi diabetes tipe \\
2 yang lebih rendah, serta kelebihan berat badan dan obesitas pada masa \\
remaja dan dewasa.
\end{tabular}

Untuk memenuhi unsur-unsur Hak anak yang berusia 0-6 bulan dalam pemberian ASI Eksklusif dan Hak tenaga kerja wanita dalam mensejahterakan keluarganya diperlukannya elemen-elem seperti siapapemeganghaktersebut, siapayang yang berkewajiban untuk mewujudkan hak itu dan apa yang menjadi substansi dari hak yang dimaksud. Idealnya suatu produk hukum mengakomordir system hukum sebagaimana dikemukakan oleh Friedman agar dalam penerapannya tidak bermasalah. ${ }^{11}$

11 Ni Ketut Supasti Dharmawan, 2010, A Hybrid Framework Suatu Alternatif Pendekatan CSR (Corporate Social Responsibility) Di Indonesia, Jurnal Ilmiah Fakultas Hukum Universita Udayana (Kertha Patrika), vol. 34, no. 1 , hlm. 12 .
Negara (pemerintahan daerah Provinsi Bali) sebagai pemegang otoritas dan legitimasi, diwajibkan untuk menyusun dan menjalankan kebijakan baik yuridis maupun nonyuridis dalam pemenuhan hak-hak tersebut. ${ }^{12}$ Menurut Henry Shue, setiap hak mempengaruhi tiga jenis kewajiban atau trokotomi kewajiban yakni: 1) forbearance duties (kewajiban kesabaran), 2) protection duties (kewajiban perlindungan), assitance duties (kewajiban perbantuan). ${ }^{13}$ Untuk

12 IGN Parikesit Widiatedja, 2011, Kebijakan Liberalisasi Pariwisata, Udayana University Press, Denpasar, hlm. 68.

13 Majda El Muhtaj, 2013, Dimensi-Dimensi HAM Mengurai Hak Ekonomi, Sosial, dan Budaya, Cet ke-3, PT Raja Grafindo Persada, Jakarta, hlm. 43. 
menegakan Hak anak yang berusia 0-6 bulan dalam pemberian ASI Eksklusif dan Hak tenaga kerja wanita dalam mensejahterakan keluarganya kaitan yang erat terhadap sistem hukum yang terdiri atas tiga komponen, yakni: Legal Substance, Legal Structure dan Legal Culture, dan menyatakan "The substance is composed of substantive rules and rules about how institutions should behave"14.

Dalam rangaka melaksanakan kebijakan nasional dalam rangka program pemberian ASI Eksklusif di Provinsi Bali, memperhatikan kemampuan dan potensi sumber daya manusia serta Hak-hak Konstitusi terhadap bayi dan pemberi ASI Eksklusif serta dukungan masyarakat dengan strategi program pemberian ASI Eksklusif dilakukan secara terpadu, berjenjang, berkelanjutan dan berkesinambungan. Maka ketentuanketentuan dalam membentuk Peraturan Daerah Di Provinsi Bali harus sesuai dengan yang diatur dalam PP ASI Eksklusif seperti:

1. Latar Belakang dan Tujuan Penyusunan

Dengan Maksud memberikan perlindungan secara hukum dan kesempatan bagi bayi untuk mendapatkan hak dasarnya dimanapun berada. Dengan Tujuan menjamin

14 Lawrance M. Friedman, 1975, The Legal System: a Social Science Perspective, Russel Sage Foundation, New York, p.14. pemenuhan hak Bayi untuk mendapatkan ASI Eksklusif sejak dilahirkan sampai dengan berusia 6 (enam) bulan dengan memperhatikan pertumbuhan dan perkembangannya.

2. Sasaran Yang Ingin Diwujudkan Keberhasilan pembangunan kesehatan antara lain adalah penurunan angka kematian Bayi. Pola pemberian makan terbaik untuk Bayi sejak lahir sampai anak berumur 2 (dua) tahun meliputi: (a) memberikan ASI kepada Bayi segera dalam waktu 1 (satu) jam setelah lahir; (b) memberikan hanya ASI saja sejak lahirsampaiumur6(enam) bulan. Menyusui menunda kembalinya kesuburan seorang wanita dan mengurangi risiko perdarahan pasca melahirkan, kanker payudara, pra menopause dan kanker ovarium; (c) memberikan Makanan Pendamping ASI (MPASI) yang tepat sejak genap umur 6 (enam) bulan; dan (d) meneruskan pemberian ASI sampai anak berumur 2 (dua) tahun. Penerapan pola pemberian makan ini akan meningkatkan status gizi Bayi dan anak serta mempengaruhi derajat kesehatan selanjutnya.

3. Pokok Pikiran, Lingkup, atau Objek Yang Akan Diatur

Hak konstitusional bayi serta kewajiban ibu (pemberi ASI Eksklusif) adalah bagian dari hak asasi manusia yang wajib dijamin, dilindungi, dan dipenuhi 
oleh Orang Tua, masyarakat, pengusaha/ perusahaan (tempat ibu/ pemberi ASI Eksklusif bekerja), negara, pemerintah, dan pemerintah daerah. Yang seharusnya diperlakukan khusus untuk memperoleh kesempatan dan manfaat yang sama guna mencapai persamaan dan keadilan dengan pertimbangan moral dan etika.

4. Jangkauan dan Arah Pengaturan Sebagai orang tua/ wali dari bayi tersebut wajib memberikan ASI Eksklusif, apabila ibu dari bayi tersebut dikarenakan tidak bisa menyusui bayi tersebut, maka diharuskan mencari pendonor ASI. Sebagai masyarakat yang bermoral dan beretika Pancasila harus mendukung untuk si ibu/ pemberi ASI Eksklusif demi kesehatan bayi. Sebagai pengusaha/ perusahaan (tempat ibu/ pemberi ASI Eksklusif bekerja) wajib memberikan kompensasi waktu dalam bekerja, menyediakan ruangan khusus bagi ibu/ pemberi ASI Eksklusif untuk memompa ASI yang akan diberikan kepada bayi tersebut, dilarang memberikan tugas seperti ke luar kota, keluar Provinsi ataupun ke luar negeri di karenakan ibu ataupun bayi sangat rentan sakit. Sebagai pemerintah daerah Provinsi Bali wajib membuat dan membentuk suatu regulasi atau peraturan untuk mengamalkan
PP ASI Ekslusif agar terciptanya kepatuhan bagi seluruh orang tua, masyarakat, pengusaha/ perusahaan guna pembangunan kesehatan anak di Provinsi Bali sebagai penerus generasi yang akan datang dan memberikan berkelanjutan di masa yang akan datang.

\section{PENUTUP}

\subsection{Simpulan}

1. Dikarenakan tidak adanya aturan tertulis atau kekosongan norma mengenai pengaturan ASI eksklusif di Pemerintahan Provinsi Bali yang merupakan Hak Anak dalam terpenuhinya kesehatan dasar serta Hak wanita dalam perlakuan khusus dalam tanggung jawabnya memberikan ASI kepada anaknya walaupun wanita tersebut sedang bekerja. Dalam Pasal 4 huruf d yaitu Pembangunan ketenagakerjaan bertujuan meningkatkan kesejahteraan tenaga kerja dan keluarganya. Secara eksplisit pasal inimemberikankemudahan bagi tenaga kerja wanita untuk mensejahterakan bayi dengan cara memberikan ASI Eksklusif walaupun ibu sedang bekerja. Dimana dalam hal ini Pasal 129 ayat (1) UU Kesehatan Pemerintah bertanggung jawab menetapkan kebijakan dalam rangka menjamin hak bayi untuk mendapatkan air susu ibu secara eksklusif. Yang 
dijabarkan Pasal 1 angka 2 PP ASI Eksklusif Air Susu Ibu Eksklusif yang selanjutnya disebut ASI Eksklusif adalah ASI yang diberikan kepada Bayi sejak dilahirkan selama 6 (enam) bulan, tanpa menambahkan dan/ atau mengganti dengan makanan atau minuman lain.

2. Untuk melaksanakan kebijakan nasional dalam rangka program pemberian ASI Eksklusif di Provinsi Bali, memperhatikan kemampuan dan potensi sumber daya manusia serta Hakhak Konstitusi terhadap bayi dan pemberi ASI Eksklusif serta dukungan masyarakat dengan strategi program pemberian ASI Eksklusif dilakukan secara terpadu, berjenjang, berkelanjutan dan berkesinambungan. Dalam mensejahterakan keluarganya harus disusun dalam perencanaan penyusunan yang dilakukan oleh Program Legislasi Daerah (Prolegda) Provinsi yang telah melalui pengkajian dan penyelarasan dituangkan dalam Naskah Akademik sehingga dapat mencegah tumpang tindih pengaturan atau kewenangan. Dengan 1) Latar Belakang dan Tujuan Penyusunan; 2) Sasaran Yang Ingin Diwujudkan; 3) Pokok Pikiran, Lingkup, atau Objek Yang Akan Diatur dan; 4) Jangkauan dan Arah Pengaturan.

\subsection{Saran}

1. Dikarenakan tidak adanya aturan tertulis atau kekosongan norma mengenai pengaturan ASI eksklusif di Pemerintahan Provinsi Bali yang merupakan Hak Anak dalam terpenuhinya kesehatan dasar serta Hak wanita dalam perlakuan khusus dalam tanggung jawabnya memberikan ASI kepada anaknya walaupun wanita tersebut sedang bekerja. Maka diperlukannya Peraturan Daerah dibidang ASI Esklusif.

2. Untuk melaksanakan kebijakan nasional dalam rangka program pemberian ASI Eksklusif di Provinsi Bali, memperhatikan kemampuan dan potensi sumber daya manusia serta Hakhak Konstitusi terhadap bayi dan pemberi ASI Eksklusif serta dukungan masyarakat dengan strategi program pemberian ASI Eksklusif dilakukan secara terpadu, berjenjang, berkelanjutan dan berkesinambungan di Pemerintahan Provinsi Bali: 1) merancang dan membentuk Perda yang diselaraskan dengan PP ASI Eksklusif;2) membangun ruangan pojok ASI fasilitas pelayanan kesehatan, tempat proses belajar mengajar, tempat ibadah, tempat kerja, fasilitas pariwisata, dll; 3) memberikan kompensasi waktu dalam bekerja tanpa mengurangi upah. 


\section{DAFTAR PUSTAKA}

\section{Buku:}

Dasril Radjab, 2005, Hukum Tata Negara Indonesia, Rineka Cipta, Jakarta.

IGN Parikesit Widiatedja, 2011, Kebijakan Liberalisasi

Pariwisata, Udayana University Press, Denpasar.

Lawrance M. Friedman, 1975, The

Legal System: a Social Science

Perspective, Russel Sage

Foundation, New York.

Majda El Muhtaj, 2013, Dimensi-

Dimensi HAM Mengurai Hak

Ekonomi, Sosial, dan Budaya,

Cet ke-3, PT Raja Grafindo

Persada, Jakarta.

Mukti Fajar dan Yulianto Achmad, 2010, Dualisme Penelitian Hukum Normatif dan Empiris,

PT Pustaka Pelajar, Yogyakarta.

Siswanto Sunarno, 2006, Hukum

Pemerintahan Daerah di

Indonesia, Sinar Grafika, Jakarta.

Soerjono Soekanto, 2011, Faktor-

Faktor Yang Mempengaruhi

Penegakan Hukum, Cetakan kesepuluh, PT Raja Grafindo Persada, Jakarta.

Yuliandri, 2013, Asas-Asas Pembentukan Peraturan

Perundang-Undangan Yang

Baik, Cetakan ke IV, PT Raja Grafindo Persada, Jakarta.
Jurnal:

Diah Fitriani, Penjabaran Hak Tenaga Kerja Perempuan Atas Upah Dan Waktu Kerja Dalam Peraturan Perusahaan Dan Perjanjian Kerja, Jurnal Magister Hukum Udayana (Udayana Master Law Journal), vo.4, no. 2, Tahun 2015, Edisi Juli 2015.

Ni Ketut Supasti Dharmawan, $A$ Hybrid Framework Suatu Alternatif Pendekatan CSR (CorporateSocialResponsibility) Di Indonesia, Jurnal Ilmiah Fakultas Hukum Universita Udayana (Kertha Patrika), vol. 34, no.1, Tahun 2010, Edisi Januari 2010.

Putu Eva Laheri, Tanggung Jawab Negara Terhadap Kerugian Wisatawan Berkaitan Dengan Pelanggaran Hak Berwisata Sebagai Bagian Dari Hak Asasi Manusia, Jurnal Magister Hukum Udayana (Udayana Master Law Journal), vol. 4, no. 1, Tahun 2015, Edisi Mei 2015.

\section{Media Cetak:}

Tribun Bali, 27 Juni 2015, Angka Kematian Ibu dan Bayi di Bali Menurun di Tahun 2015.

\section{Peraturan Perundang Undangan:}

Undang Undang Dasar Negara Republik Indonesia Tahun 1945 Undang Undang Nomor 39 Tahun 1999 Tentang Hak Asasi Manusia (Lembaran Negara Republik Indonesia Tahun 1999 
Nomor 165 Tambahan Lembaran

Negara Nomor. 3886)

Undang Undang nomor 13 Tahun

2003 Tentang Ketenagakerjaan

(Lembaran Negara Republik Indonesia Tahun 2003 Nomor

39 Tambahan Lembaran Negara Nomor. 4279)

Undang Undang Nomor 36 Tahun 2009 Tentang Kesehatan (Lembaran Negara Republik Indonesia Tahun 2009 Nomor 144 Tambahan Lembaran Negara Nomor. 5063)

Undang Undang Nomor 12 Tahun 2011 Tentang Pembentukan Peraturan Perundang Undangan (Lembaran Negara Republik Indonesia Tahun 2011 Nomor 82 Tambahan Lembaran Negara Nomor. 5234)

Undang Undang Nomor 23 Tahun 2014 Tentang Pemerintahan Daerah (Lembaran Negara Republik Indonesia Tahun 2014 Nomor 244 Tambahan Lembaran Negara Nomor. 5587)

Peraturan Pemerintah No. 6 Tahun 2010 Tentang Satuan Polisi Pamong Praja (Lembaran Negara Republik Indonesia Nomor 9 Tambahan Lembaran Negara Nomor. 5094)

Peraturan Pemerintah Nomor 33 Tahun 2012 Tentang Pemberian Air Susu Ibu Eksklusif (Lembaran Negara Republik Indonesia Nomor 58 Tambahan Lembaran Negara Nomor. 5291)
Peraturan Menteri Negara Pemberdayaan Perempuan dan Perlindungan Anak Republik Indonesia Nomor 11 Tahun 2011 Tentang Kebijakan Pengembangan Kabupaten/Kota Layak Anak (Berita Negara Republik Indonesia Nomor 168). 